\title{
Challenges of good governance and sustainable development in democratic Nigeria
}

\author{
Inuwa Abdu Ibrahim \\ Department of Public Administration, Federal Polytechnic, Bauchi, Nigeria
}

\begin{abstract}
The research examined the governments' failure in achieving good governance and sustainable development. How leaders have used their latent functions in governance and its resultant consequence. How investment in education and human capital development could solve the problem of good governance and sustainable development. The paper therefore focuses on the education sector and human capital development, using secondary sources of data. In conclusion, the research offers education and human capital development as the key remedies to the challenges of good governance and sustainable development in a democratic Nigeria.
\end{abstract}

Keywords: Education; Human Capital; Nigeria; Development; Government and Governance

\section{INTRODUCTION}

The return to civilian rule on the $29^{\text {th }}$ of May, 1999 brought with it great expectations of socio-economic development. Sadly, fourteen years later these expectations are yet to be achieved. Under a democratic setting the state exists to ensure the overall welfare of its citizens. Thus, the state is a natural design for promoting social good and public welfare (Okoli, 1990). It is apt to state that Nigeria since independence has failed to attain a level of development compared to the countries that achieved independence around the same time.

Failure of leadership has been identified as the reason for bad governance and deteriorating state of development in Nigeria. According to (Ojo, 2005) "the democracy in the African context serves the interest of only the ruling class". Politicians are more concerned with looting public funds and ensuring their grip on power. In the political, civil, economic, social and spiritual arenas, recent events indicate that previous generations have produced a poor quality of characters that fade in the presence of true leadership and leave our present generation in this same leadership vacuum (Munroe, 1993).

\section{EDUCATION AND HUMAN CAPITAL DEVELOPMENT}

Education remains the key to a country's human capital development. It is the basis by which human capital of a nation is developed and sustained; and the rate at which a nation's education system transfers knowledge and skills greatly affects development. Developing education results in economic growth, quantitative and qualitative labour force. Failure of governments (especially in less developed countries- L.D.Cs, like Nigeria) to invest 
appropriately in education leads to widening a development gap. Including; illiteracy, unemployment, and income inequalities.

In Nigeria, the epileptic financing of capital projects to erect standard and adequate facilities is second only to the virtual neglect of human capital characterised by poor working conditions of teachers/lecturers thus, the brain drain syndrome. All these affect the quantity and quality of both teachers and students.

Investment in human capital contributes to productivity by raising the rate of human capital formation. It is even identified that investment in people has been a major source of economic growth in More Developed Countries (MDCs), even though such investment is being neglected in the L.D.Cs, which in turn leads to economic backwardness manifesting in low labour efficiency, factor immobility, limited specialization and deficient supply of entrepreneurship (Meier, 1984).

Nigeria is characterised by recurrent and lingering strikes by academics and non academics at different levels of the education system. The current Academic Staff Union of Universities (ASUU) Strike is an example of how much education and human capital have been neglected. Perhaps (Jideofor, 2013) sums it up like this:

That the Nigerian education system is in severe crisis is self-evident. If the increasing trend of our university graduates being unable to read and write not enough evidence, then the virtual absence of our universities in upper end of the league of African Universities should suffice. And if you are still not convinced, you can read the articulation of the Academic Staff Union of Universities (ASUU) during its annual strikes.

Most public schools and institutions of higher learning are characterised by dilapidated structures, overcrowding in classes, poor salaries and working conditions. Government insists that the money is simply not there yet; according to the cover story of the (Dailly Trust, 2013) the salary package of Nigerian federal legislators surpasses that of Britain, South Africa and the United States. Also according to (Daily Trust NewsPaper, 2013) Nigeria pays its ministers higher salaries and allowances in comparison to the previously stated states. The answers could be found by understanding the dominant behaviour of leaders in the developed countries and the ones in the developing countries (Mbaya, 2012). This brings us to the concepts of latent and manifest functions as put forward by (Parsons, 1960). Manifest functions include great sense of transparency and accountability where leaders are seen as public servants. This is the dominant features of the more developed states. Latent functions arises as a result of changing (officially or unofficially) of administrative processes to suit their personal interests. Features of latent functions are looting of public treasury, rigid towards constructive criticism and intolerance to any form of opposition etcetera despite agreed democratic principles.

\section{CHALLENGES OF GOVERNMENT AND GOVERNANCE}

According to (Eyiyere, 1997), government refers to the whole machinery through which a country is ruled. All governments are unique, in the sense that cultural and historical realities greatly influence the nature and practice of government in a state.

(Vision 2020:20 Report, 2010) States that governance is 'the traditions and institutions by which authority in a country is exercised for the common good'. The report added that 'governance deals with the national systems as a whole - how it is constituted and how it 
works, with stakeholders, the actors, and the processes involved'. The Nigerian experience has been quite the opposite, where you find government and governance favouring those in government and their allies.

This has led us to our current reality; unwillingness of government to genuinely invest in its people without any form of strike from relevant stakeholders - ASUU strikes. Such strikes try to pressure government to deliver on good governance and investment in human capital development. The strike by an umbrella unit of the university lecturers on the 24 of June, 2009 over governments refusal to endorse a 2006 agreement that would give the education sector 26 percent of its annual budget as well as implement a new salary structure (Jideofor, 2013).

Over the years Nigerians have had governments with promises of national development, only to be betrayed at the end. One of such government was that of President Obasanjo, which came with promises of efficient power supply, economic revitalization etcetera. Perhaps, (Dowden, 2008) sums it best;

With the legacy of sixteen years of bad military rule, strong international support and a six fold increase in Nigeria's oil revenues during Obasanjo's eight years as president, it is hard to find exactly how he managed to end his reign as just about the most unpopular man in Nigeria. When he came to power, he had all the cards. He could have bought off or charmed opponents, taken steps such as providing electricity and clean water. He could have left a legacy of real change, a transformed Nigeria, but Obasanjo left office discredited and disgraced.

Several challenges to good governance have been postulated, according to the (African Peer Review Mechanism, 2009) centralization 'of power, security and financial resources in the Federal government" has led to its inefficiency. It also added that 'the dichotomy between ethnic indigene ship and civic citizenship has been the cause of many conflicts at the communal and state levels as access to services and resources depends on which category one belongs to" this challenge could be rectified with adequate concentration on education, education is the vehicle for building better human capacity, understanding, participation and tolerance. The result will be good governance and overall socio-economic development of the Nigerian state.

\section{CONCLUSION}

It is apt from the foregoing that getting the adequate number of people with the necessary education and experience is pertinent to economic and political development which is seen as good governance and human capital development. Human capital formation or accumulation is the process of acquiring and increasing the number of persons who have the skills, education and experience. Which are required to achieve economic and political development (Jinghan, 1997).

That there exist challenges to good governance in Nigeria which if not checked could spell doom for its people and the development of the Nigerian state. Government and its policies are generally viewed as servicing the interests of those in government and their allies. 


\section{Recommendation}

Presidential democracy under a federal set up remains relevant to Nigerians, however the challenge lies with the followings:

- The latent functions of the leaders, and

- The abuse of the education section.

I recommend the following measures as a way out of the challenges of good governance and sustainable development in a democratic Nigeria:

Organized stakeholders in the country like ASUU and the Nigeria Labour Congress should engage government through dialogue, threat of, and even productive industrial actions. As seen in recent history, Nigeria most a times respond only to strikes. Such actions would help in checking the latent functions of the leaders. For government to achieve good governance and the attainment of sustainable development it must invest in its people by building capacity. This can be achieved only through a well structured and lubricated education sector. The future of Nigeria and indeed any state is to educate its citizens.

The youths are the future of any country thus; a country that fails to empower its people through education is a country with no future. Established political pressure groups should do more in mobilizing the electorate in ensuring that their votes count. The result of this is a scenario where credible leaders are allowed to contest and win elections. Again, the principle of 'recall' as enshrined in the constitution should be used as a weapon of ensuring public service by members of the national assembly. The economic and financial crimes commission should be empowered, by making it financially and administratively independent of the executive arm of government. This would help them in discharging their duties without fear or favour. The judiciary being the last hope of the masses must be truly independent of the other branches of government if we are to ensure good governance and its sustainability. It must be financially independent, which could be solved by establishing a special fund for the judiciary by passing the necessary bill(s). Which must also guarantee tenure of judges as well as giving the judicial service commission the power of appointment and promotion for judges based on seniority, record, and qualification among other universally acceptable principles?

A national reorientation and reawakening policy should also be vigorously pursued by the government through the education sector and the ministries of information at the Federal and State levels.

\section{References}

[1] African Peer Review Mechanism. (2009). Africa Peer Review Mechanism (APRM). Nigeria Country Report.

[2] Dailly Trust, N. (2013, July 22). Nigerian Lawmakers Top Salaries Chart. Daily Trust Newspaper, p. 1.

[3] Daily Trust News Paper. (2013, July 25). Nigeria Pays Ministers Higher Than U.S, U.K, S.A. Daily Trust NewsPaper, p. 1.

[4] Dowden, R. (2008). Africa: Altered States. Ordinary Miracles.

[5] Eyiyere, D. (1997). Government Made Easy (3rd Edition). Benin: Doe - Sun.

[6] Jideofor, A. (2013, August Thursday 22nd). ASUU, government, and dialoguing with the deaf. Daily Trust News Paper, p. 64. 
[7] Jinghan, M. L. (1997). The Economics of Development and Planning. Delhi: Vrinda Publications.

[8] Mbaya, P. (2012). Elements of Government and Administration. Maiduguri: Global ComputeRay.

[9] Meier, G. M. (1984). Leading Issues in Economic Development (4th Edition). Oxford: Oxford University Press.

[10] Munroe, M. (1993). Becoming a Leader: Every one can do it. U.S.A: Pneuma life.

[11] Ojo, S. (2005). Democritisation and Democratic struggles. In A. Ikelegbe, Introduction to Politics (p. 8). Benin: Imprint.

[12] Okoli, E. F. (1990). Foundations of Governments and Politics. Onitsha: Africana-fep.

[13] Parsons, T. (1960). Structure and Process of Modern Society. In D. f. Mobilization, Political Education Manual: Directorate for Social Mobilization. Abuja: Free Press.

[14] Vision 2020:20 Report. (2010). Vision 2020:20 Report. Abuja: Federal Republic of Nigeria.

[15] Borowski A., International Letters of Social and Humanistic Sciences 1 (2013) 14-18.

[16] Borowski A., International Letters of Social and Humanistic Sciences 4 (2013) 70-74.

[17] Sylvester Tabe Arrey, International Letters of Social and Humanistic Sciences 10 (2013) 32-45.

[18] Abdurakhim Fayziev, International Letters of Social and Humanistic Sciences 10 (2013) 46-53.

[19] Joseph Besigye Bazirake, Paul Bukuluki, International Letters of Social and Humanistic Sciences 10 (2013) 54-72.

[20] Jima Dilbo Denbel, International Letters of Social and Humanistic Sciences 10 (2013) 73-83.

[21] Paul Bukuluki, John David Kisuule, Alex Bagabo Makerere, Berit Schei, Johanne Sundby, International Letters of Social and Humanistic Sciences 10 (2013) 84-102.

[22] Borowski A., International Letters of Social and Humanistic Sciences 11 (2013) 100-105.

[23] Pawa Tersoo, International Letters of Social and Humanistic Sciences 3 (2014) 26-36.

[24] Rabi'u Muhammad Ishaq, International Letters of Social and Humanistic Sciences 3 (2014) 37-44.

[25] Adoga James Ada, International Letters of Social and Humanistic Sciences 3 (2014) 45-52.

[26] Abubakar Aminu Boyi, International Letters of Social and Humanistic Sciences 3 (2014) 65-72.

[27] Alaba E. Dare, International Letters of Social and Humanistic Sciences 3 (2014) 73-79.

[28] Kabiru Ibrahim Yankuzo, International Letters of Social and Humanistic Sciences 4 (2014) 1-8. 
[29] Onyike Maggaret Odu, International Letters of Social and Humanistic Sciences 4 (2014) 31-39.

[30] Uloma Charity Oguzor, International Letters of Social and Humanistic Sciences 4 (2014) 97-104.

[31] Okezie A. Ihugba, Bankoli Bankong, N. C. Ebomuche, International Letters of Social and Humanistic Sciences 5 (2014) 92-113. 